УДК 159.9: 14

Ольга Радченко

doi: 10.15330//vpufpn.22.38-45

\title{
ПОЗИТИВНА ПСИХОТЕРАПІЯ ТА ІІЇ ВПЛИВ НА СВІТОГЛЯД УКРАЇНЦІВ: ФІЛОСОФСЬКО-ПСИХОЛОГІЧНИЙ АСПЕКТ
}

Вплив позитивної психотерапії на світогляд сучасних украӥнців досліджуеться у цій статті з філософсько-психологічного аспекту. Базові здатності людини любити і знати, мікро- $і$ макроподї, модель балансу, принципи позитивної психотерапії сприяють суб'єктності $і$ розииренню світогляду сучасних україниів.

Ключові слова: позитивна психотерапія, світогляд, філософія психологї, базові здатності любити i знати, мікро- $і$ макроподіï, модель балансу, принциии позитивної психотерапії.

Світогляд особистості тісно пов'язаний зі світоглядом мікро- і макроспільнот, до яких вона належить. Світорозуміння, світовідчуття суттєво впливають на якість життя людини і спільноти, тому є в предметному полі досліджень психології і філософії. На думку Г. Дичковської, ідеологія як відображення буття людини і суспільства залежить від онтологічно-екзистенційного самосприйняття колективного суб'єкта, є своєрідним колективним розгортанням архетипічної самості в діяльнісно-практичну площину [3, c. 19].

Загально теоретичний тисячолітній здобуток філософів стає основою і для сучасних психологічних досліджень. Зокрема, філософсько-психологічний (міждисциплінарний) підхід сприяє вирішенню сенсожиттєвих проблем особистості, яка потребує психологічної допомоги. Чергове зближення в історії розвитку цих двох наук спостерігається у XX ст., коли психологія і філософія здобувають все більше сфер ресурсного взаємовпливу, зокрема, i на світоглядному рівні. Сьогодення сприяє такому взаємозв'язку й на міжкультурному, загальнолюдському рівні у пошуку відповідей на стратегічні філософсько-психологічні проблеми. Це відображається і в сучасному українському світогляді, індивідуальному і колективному.

Світоглядні проблеми у психології розглядають провідні вчені. Зокрема, К. Роджерс, А. Маслоу, В. Франкл, Е. Фромм, А. Швейцер, М. Шелер, К.Г. Юнг, К. Ясперс та ін. 3поміж українських науковців, які розробляють цю проблему, варто виокремити у контексті нашого дослідження напрацювання Г. Дичковської [2], О. Донченко [3], 3. Карпенко [4], Ю. Романенка [3]. Звісно, безумовною опорою слугують праці засновника методу позитивної психотерапії Носсрата Пезешкіана [5-8]. Метою цієї статті $є$ спроба філософсько-психологічного осмислення впливу позитивної психотерапії на світогляд українців.

Метод позитивної психотерапії створений у співпраці з колегами та описаний Носсратом Пезешкіаном у 1960-х рр. Цей новий конфлікт-центрований гуманістичний метод фокусується на позитивних аспектах конфліктів, ресурсах та здібностях людини, спирається на результати транскультуральних психологічних досліджень. 31977 р. відбувається активний розвиток методу: Н. Пезешкіан засновує Вісбаденський інститут підготовки психотерапевтів і сімейних терапевтів (WIPF), акредитований державною медичною палатою для післядипломної освіти лікарів в області психотерапії. У 1996 р. метод позитивної психотерапії офіційно визнаний Європейською асоціацією психотерапії (EAP).

Розвиток позитивної психотерапії в Україні започатковується у 1992 р. Тоді син і послідовник засновника цього методу Навид Пезешкіан проводить ознайомчі семінари у Києві, Полтаві, Черкасах. Позитивна психотерапія добре адаптується і поширюється в українському психологічному просторі. У 1999 р. відбувається офіційне визнання методу позитивної психотерапії Українською спілкою психотерапевтів (УСП). Відтоді в Україні активно здійснюються довготривалі сертифіковані програми. Носсрат Пезешкіан відвідує Україну у 2007 р., проводить семінари та супервізії. За даними сайту WAPP (Всесвітньої 
асоціації психотерапії та кроскультурної психотерапії) на лютий 2019 р. в Україні зареєстровано 12 центрів позитивної психотерапії (5 - у Києві, 4 - в Одесі, 2 - у Черкасах, 1 - в Івано-Франківську) [10]. Відбувається навчання на базис- і майстер-курсах, проводяться наукові, науково-практичні конференції, семінари тощо. Таким чином, українці навчаються основ консультування, психотерапії у методі позитивної психотерапії, здобувають клієнтський досвід, досвід самодопомоги. Це сприяє оздоровленню від психотравм, світоглядним змінам як учасників проекту, так і їх оточення.

Насамперед визначимо поняття світогляду. Світогляд $\epsilon$ сукупністю знань, переконань, оцінок, поглядів, мотивів, емоцій, почуттів, принципів, які визначають загальне бачення та розуміння, почування особи, світу, особи у світі. Це виражається у життєвій позиції, програмі поведінки, діяльності. Світогляд людини зумовлений особливостями суспільного буття та соціальними умовами. Світогляд властивий кожній особі, незалежно від того, чи є він раціонально усвідомлений [1].

Таку єдність раціонального й ірраціонального у світогляді чудово відображає позиція позитивної психотерапії як ресурсно орієнтованого методу психотерапевтичної допомоги для осіб, пар, сімей. Її можна охарактеризувати як гуманістичну і транскультурну психодинамічну психотерапію, засновану на позитивній концепції людської природи і принципах салютогенезу. Цей метод відкритий для включення інших методів на благо клієнтів, що корисне для консультування. Позитивна психотерапія виходить на концептуальне розуміння сутності людини, що уможливлює іiї адаптоване використання як методу психологічної допомоги у різних країнах, культурах. Звернімося до розгляду філософсько-психологічних основ позитивної психотерапії для виявлення світоглядного впливу на світогляд українців.

Позитивна психотерапія наголошує на цілісному баченні життя людини (холістичному підході), на оптимістичному сприйнятті іiі природи. Це реалізується застосуванням відповідних складових цього методу: 1) Positum-підхід (позитивний - той, що є в дійсності, реальний, конкретний [10]), що базується на принципі надії щодо конструктивної природи людини, iï здатності вирішити власні проблеми; 2) психодинамічний диференційний аналіз змісту конфліктів, що базується на принципі гармонізації актуальних та базових здібностей "Знати" та “Любити"; 3) 5-крокова стратегія психотерапевтичної допомоги на основі принципу консультування; 4) моделі балансу і наслідування; 5) минуле і теперішнє конфліктоцентрованого підходу є основою для майбутнього - особистості 3 новими можливостями, ідентичністю, ресурсами, взаємодією 3 власними сенсами. За словами Носсрата Пезешкіана, людина вчиться взаємодіяти зі своїм минулим, осягати своє неповторне минуле як дзеркало теперішнього і майбутнього [5, с. 59]; 6) транскультурне мислення; 7) розгляд людини, їі проблеми у контексті значущої соціальної групи, сім’ї, коли члени сім’ї як індивідууми і соціальні фактори як визначальні умови включаються у терапевтичний процес; 8) метатеоретичні, метапрактичні аспекти - змістом позитивної психотерапії є концепція, у межах якої можуть раціонально застосовуватися і взаємно доповнюватися різні методи і спеціальні напрями.

У позитивній психотерапії людина постає як цілісність тілесного і психічного (душевного, духовного). При цьому науково розглядаються питання про взаємовплив соматичних, психічних та духовних феноменів. Дуалізм тіла і душі (психічного) є однією 3 рис українського менталітету. Загалом позитивна психотерапія сприяє залученим до неї українцям краще зрозуміти себе, власну ідентичність, сутність подій, взаємин, шляхів нормалізації конфліктних ситуацій у балансі 4-х базових сфер людського життя: тілесної, діяльнісної, емоційної, сенсової.

Позитум-підхід у позитивній психотерапії спирається на ресурсне уявлення про людину, добру за своєю суттю. Поєднуються раціональний і ірраціональний шляхи дослідження психіки, тіла на основі надії, виходу на сенси, майбутнє. Метафори, притчі, історії, афоризми, анекдоти, приказки, у яких закладений досвід попередніх поколінь, їхня мудрість, шляхи нормалізації життєвості широко використовуються у роботі з клієнтами. 
Крос-культурний підхід звертає нашу увагу на досвід інших й інакших людей, культур. Те, що є нормою в одній культурі, може вважатись дивацтвом або відхиленням в іншій. Чим ширше, кроскультурніше ми дивитимемося на конфлікт, тим більше шляхів його вирішення побачимо, розширюючи горизонти власних можливостей і прагнень, дозволів $\mathrm{i}$ реалізацій.

Позитивна психотерапія насамперед спрямована на розвиток людини, на те, як навчитися самодопомозі. В іiї основі таке розуміння людини та іï природи:

1) кожна особа $є$ джерелом, регулятором власних проблем і конфліктів. Ця позиція $\epsilon$ особливо цінною у сучасному українському менталітеті, де широко поширена токсична модель взаємин насильник-жертва-рятівник. Позитивна психотерапія дає можливість дослідити джерела виникнення проблеми у житті людини, виявити “бонуси”, породжені цією проблемою. Психотерапевт супроводить клієнта до власного пошуку бажаного рішення і його здійснення. Таким чином, відбувається трансформація свідомості клієнта 3 позиції об’єктності, поширеного серед українців феномену “нещасної свідомості” (“хтось винен”, “я нічого не можу”, “нічого не вийде”) в опору на власні ресурси, самоцінність, якісні вибори для гармонійної взаємодії з іншими людьми, світом у новому балансі; у прийняття 100\% відповідальності за власне життя, перехід у стан творця, суб'єкта. До того ж, розширюються горизонти можливостей, мрій, посилюється мотивація, здійснюються пошуки сенсів.

2) водночас кожен $\epsilon$ й носієм здатностей та автором можливостей змін свого життя на краще, бажане. Це відповідає потребам, на які реагує сучасна психотерапія загалом та позитивна зокрема.

3 основні принципи позитивної психотерапії також спонукають українців, які працюють, консультуються у цьому методі, до більш цілісного світогляду. Розглянемо цей вплив детальніше:

1) принцип надії - кожна людина може і має шанс змінити свою реальність на краще. Тому основна увага консультанта спрямована на ресурси клієнта, що проявляються в симптомі або конфлікті. Це допомагає людині відчути свою здатність, силу обрати бажаний вихід з проблемної ситуації, повірити у себе, своє гармонійне життя та прийняти цілковиту відповідальність за своє життя. Надія на успішне вирішення проблеми власними силами 3 допомогою консультанта, інших людей, Бога, Всесвіту. Завданням психотерапевта, котрий працює в позитум-підході, є допомогти клієнту виявити здатності, знайти ресурси і навчитися на них опиратися.

Надія дає можливість уявити свої прагнення, мрії, вийти на сенси. Це якісно змінює як майбутнє, так і теперішнє людини і спільноти. Якщо звернутися до вчення А. Маслоу, то такі дозволи на майбутнє - це те, що вже є у зародку у теперішньому. Звісно, це початок змін на бажане для особи, до задоволення собою, життям, що теж дуже цінне у сучасній Україні за умов війни і потреби структурних змін у більшості суспільних сфер. Принцип надії пов'язаний з принципом балансу та гармонізації.

2) принцип балансу та гармонізації - відповідно до моделі балансу, людина живе та розвивається у чотирьох сферах, які прагнуть до природного балансу: 1 - тіло / відчуття; 2 - досягнення / діяльність; 3 - контакти / взаємини; 4 - майбутнє, призначення, сенс життя [10]. Конфлікти, дискомфорт і захворювання виникають саме в тих сферах, де є дисбаланс - дефіцит або компенсація. На основі моделі балансу діагностується наявний рівень наповненості потрібним, бажаним, здоровим або ж його відсутність; напрацьовуються шляхи для гармонізації.

Неспроможність нормально вирішити конфлікт може зумовити втечу у гіпо- чи гіперкомпенсацію: по тілу - психосоматика (симптом, хвороба, наприклад, гіпо- чи гіперфункція певного органу чи системи); діяльність - стресові фактори (лінь або трудоголізм); по емоціях - депресія (надмірна закритість чи надмір спілкування, взаємодії); по сенсах страхи, фобії (заперечення сенсів / втеча у світ ілюзій, “порожніх мрій”). Метод позитивної психотерапії шукає корінь проблеми, щоб отримати ресурс і вийти на нього; змінити 
світоглядну похибку, помилку, спрямуватися до свого справжнього “Хочу” у житті. За словами Н. Пезешкіана, якщо тобі потрібна допомога, подивися - у тебе вона є: це твої дві руки.

3) принцип консультування та самодопомоги: першочерговим завданням позитивної психотерапії є навчити людину вирішувати цю та інші свої проблеми і бути до них повсякчас готовими як до однієї з даностей життя. Найбільші заборони, страхи приховують значні ресурси зростання людини: “Де найбільше “ні”, там найбільше “так”.

Людина за своєю природою володіє 2-ма вродженими здатностями (Носсрат Пезешкіан) - любити і пізнавати:

1) здатність любити (емоційність, первинна) - це здатність людини любити і бути любимою. Обидва компоненти однаково важливі - здатність активно встановлювати, розвивати емоційні взаємини (любити) і здатність приймати і підтримувати емоційні взаємини (бути любимим). Здатність до любові різниться у своїх проявах, залежно від того, на кого вона спрямована. Це здатність емоційно-почуттєвої сфери та сфери сенсів. У своєму розвитку здатність любити розгортається у первинні актуальні здібності, такі як: любов / прийняття, віра / сенс / релігія, час, довіра, терплячість, контактність, надія, ніжність, сексуальність, наслідування, єдність, сумнів, впевненість / асертивність;

2) здатність пізнавати (когнітивність, вторинна) - здатність учитися і учити - це здатність логічного, раціонального осмислення дійсності, що розвивається на основі знань. Кожна особа намагається пізнати внутрішні зв'язки дійсності за допомогою розуму. Цікавиться, хто вона така, звідки, для чого - це питання базової людської потреби. Здатність людини ставити такі питання і шукати відповіді на них $є$ проявом когнітивності. Зі здібностей до пізнання розвиваються вторинні здібності: акуратність (щодо зовнішніх речей), охайність (щодо свого тіла), бережливість, пунктуальність, надійність, ввічливість, справедливість, вірність, послух, старання, точність, добросовісність, цілеспрямованість.

Ці 2 здатності складають сутність кожної людини. Людина від народження має всі здатності, які потрібно розвинути. Йдеться насамперед про розкриття вже закладеного потенціалу, а не наповнення ззовні. Зовнішній світ лише надає умови та інструменти самопізнання і саморозкриття.

Первинні і вторинні здатності у позитивній психотерапії позначаються як актуальні здібності, вони функціонально взаємопов'язані: відповідний розвиток однієї 3 них підтримує і полегшує розвиток іншої. Усі інші здібності можуть розвинутися 3 цих 2 базових чи розглядатися як прояви їх різних комбінацій і застосовуватися до різноманітних життєвих ситуацій. Здатність до пізнання і любові відкривають кожній людині величезні можливості. Це властива кожній людині особлива схильність, що потребує їі актуалізації і диференціації. Залежно від потреб і можливостей організму, навколишнього середовища (виховання, освіта, культура, релігія, наука тощо) ці базові здатності диференціюються в унікальну структуру рис особистості, які формують характер й індивідуальність. На думку Н. Пезешкіана, наука ближча до когнітивності, релігія - до емоційності. Релігія претендує на те, щоб давати сенс, передбачаючи обов'язковість. Наука спрямовується на віднаходження сенсу. Релігія спонукає людину бути вірною і чесною, психологія ж досліджує, чому хтось вірний чи невірний, чесний чи нечесний, як це відображається на житті людини і її партнера тощо [5].

Ця концепція про дві вроджені здатності - любити і пізнавати - співзвучна українському менталітету, схильному до емоційного сприйняття світу і пошуку відповідей про сенси, належне і щасливе життя [3, с. 207-254]. Сучасним українцям корисно і цікаво долучитися до кроскультурності, привнесеної позитивною психотерапією для: по-перше, нормалізації, відновлення самоцінності та цінності своєї любимої і люблячої людини, цінності почуттів, любові як такої у відповідальному партнерстві, унікальному для кожної пари [6; 9]. По-друге, посилення когнітивної сфери, яка у сучасному світі надзвичайно важлива, насамперед, у професійній реалізації. 
Ресурсний аспект впливу позитивної психотерапії на зичілення світогляду українців виявляється і крізь призму функиій актуальних здібностей цього методу. Розглянемо детальніше найбільш суттєві 3-поміж них:

1. Світоглядна - розширення стандартних світоглядних уявлень, виборів певного суспільства чи людини. Поведінка людини, міжособистісні та внутрішні, психічні конфлікти, що виходять за межі прийнятних у певному суспільстві, можуть бути описані в термінах актуальних здібностей як варіант бажаного вирішення проблеми, поза осудом i несхваленням.

Варто зазначити, що розширенню стандартних світоглядних виборів сучасних українців сприяє і можливість долучитися до інших культур (міграція, навчання, робота за кордоном, мандри, інтернет-ресурси). Це зменшує догматичність українського суспільства і робить його більше сприйнятливим до ресурсних змін.

2. Функиія соичіалізаціï - формування світоглядних знань, досвіду в процесі соціалізації, визначення соціумом певного нормативного рівня розвитку певних актуальних здібностей. Наприклад, для індустріального суспільства характерне нехтування первинними здібностями і надмірне акцентування на когнітивних здібностях: щоб бути прийнятим у цьому суспільстві, людина повинна відповідати його когнітивним вимогам. Сучасний український світогляд теж має дисбаланс між здібностями любити і знати. Система освіти, соціальна реалізація потребують насамперед когнітивності. При цьому потреба давати і отримувати любов відокремлюється у сферу індивідуального, менш значущого. Це відображається, з-поміж іншого, й у зниженні рівня народжуваності (як загальній тенденції старіння і вимирання населення ряду європейських країн), кількості і якості шлюбів, партнерських жіночо-чоловічих взаємин. Позитивна психотерапія досліджує стан здібностей у сфері любити і знати для їх нормалізації, відновлення і реалізації як цінності, збалансованості раціонального і почуттєвого, що сприяє психічному зціленню.

Батьки, родичі, значущі дорослі є зразком наслідування для молодших. Здебільшого дозвіл на психологічну допомогу в українському соціумі мають жінки, багато 3 яких є дружинами, мамами. Психологічна діагностика, корекція, знання, вміння, досвід самодопомоги сприяють оздоровленню психіки, тіла самої жінки, також впливають насамперед на сімейну, іноді навіть родинну систему. Збалансування актуальних здібностей $є$ корисним для дорослих, які набувають ресурсів психотерапевтичної допомоги, самодопомоги, і для їх близьких.

У деяких випадках для досягнення мети людині здається доцільним скопіювати, зобразити ті бажані актуальні здібності, які потребують дозволу і можливості проявитися. Наприклад, вихід з відмови від діяльності (ліні, апатії) починати з визнання і прийняття ситуації (що є по факту), усвідомлення користі від такої реакції, віднайдення власного “хочу” і поступового руху до діяльності “для душі”, сковородинівської “сродної праці”.

3. Ціннісно-аксіологічна - утвердження світоглядних цінностей, пріоритетів. Сфера сенсів, мрій як одна з 4-х у моделі балансу дозволяє людині виявити власні ресурси у зв'язку 3 вищою силою, спрямуватися у майбутнє. Для віруючих українців це опора на Бога. Уявлення про сутність і прояв цієї сили можуть бути різними: Всесвіт, Логос, Вищий Розум тощо. Для людей з матеріалістичною парадигмою - сила колективної підтримки чи ін. Йдеться про вихід з позиції егоїзму на кшталт “Я можу все”, доєднання до субстанції або сили, яка підтримає і допоможе наповнити сферу сенсів: як дозвіл жити у здоров 'ï, успіху, достатку, любові, реалізації задумів, мрій.

4. Конфліктологічна - пошук більш адекватних психічних настанов у виході з конфліктів. Коли надмірний прояв або відсутність актуальних здібностей викликає стан афекту, вони стають перепоною у вирішенні конфліктних ситуацій. Завдання психотерапевта виявити розбіжності у спілкуванні, діяльності, прояснити можливість прийняття чужої або корекції власної чи пошук бажаної спільної реалізації актуальної здібності. 
Сучасні українці долучаються до процесу отримання психологічної, психотерапевтичної допомоги, навчання самодопомозі при стресах і психотравмах. При цьому важливо знати про вплив мікро- і макротравм та способи взаємодії з ними.

За Н. Пезешкіаном, життєві події і мікротравми поєднуються в особистості людини на таких рівнях (запитання про 10 ключових подій крайніх 5-ти років): 1 - фізичному; 2 соціальному; 3 - духовному. Це поєднання зовнішніх перевантажень і особистісно детермінованих можливостей і здібностей для переробки цього напруження виражається актуальним конфліктом.

Американська дослідницька група Holmes and Rahe, 1967; Rahe, 1969 р. опитала репрезентативну вибірку людей у США, Швеції, Нідерландах, Японії з питанням: “Які життєві події вони вважають найважчими?” У різних культурах, країнах оцінки практично співпали, розташувалися орієнтовно так [5, с. 36].

\begin{tabular}{|l|l|c|}
\hline \multirow{2}{*}{$№$} & \multicolumn{1}{|c|}{ Подія } & \multicolumn{1}{|c|}{$\begin{array}{c}\text { Оцінка значущості, } \\
\text { максимум 100 }\end{array}$} \\
\hline 1 & Смерть дружини, чоловіка & 73 \\
\hline 2 & Розлучення & 65 \\
\hline 3 & Розлука подружжя & 63 \\
\hline 4 & Тюремне ув'язнення & 63 \\
\hline 5 & Смерть одного з близьких родичів & 53 \\
\hline 6 & Травма, хвороба & 50 \\
\hline 7 & Весілля & 47 \\
\hline 8 & Звільнення з роботи & 45 \\
\hline 9 & Усиновлення дитини & 45 \\
\hline 10 & Вихід на пенсію & 16 \\
\hline & ................ & 15 \\
\hline 38 & Зміна ритму сну/ бадьорості & 15 \\
\hline 39 & Зміна складу сім’і & 13 \\
\hline 40 & Зміна звичок у їжі & 11 \\
\hline 41 & Канікули & \\
\hline 42 & Різдво & 12 \\
\hline 43 & Незначні порушення закону & \\
\hline
\end{tabular}

Макроподія - несподіване сильне навантаження, коли психіка людини не має досвіду вирішення такої чи подібної проблеми, що може спричинити психічну травму. Наприклад, перша смерть близької людини є дуже травмуючою. Надалі психіка вже має адаптивні механізми, тому подальші смерті близьких сприймаються не як психотравма, а як стрес (різної інтенсивності).

Мікроподії мають ефект накопичення, снігової лавини. Українська народна мудрість каже, що крапля камінь точить. Своєчасно не пропрацьовані, вони досягають ефекту макротравми у піковій точці. Проте, оскільки підготовчий період до загострення був тривалим, людина зазвичай легше перепрацьовує цей конфлікт. I макро-, і накопичувані мікротравми потребують уваги, за потреби - супроводу спеціаліста для відновлення психічного здоров'я, доброго самопочуття людей.

Підсумовуючи, зазначимо, що позитивна психотерапія з 1992 року поширюється в Україні і впливає на нормалізацію світогляду українців. Цей вплив 3 філософськопсихологічної позиції виявляється насамперед у двох ключових моментах: 
1 - підвищення самооцінки, самоцінності; покращення рівня обізнаності, досвіду щодо психічного і фізичного здоров'я, потенціалу особи: від усвідомлення та прийняття позитуму (профілактики, діагностики, виходу з конфлікту) до переходу у власну відповідальність за своє життя у здоров’ї, успішній діяльності, збалансованості здатностей любити і знати, прагненні до бажаного, потрібного, сенсів і мрій;

2 - розширення світоглядної багатоманітності, ресурсних дозволів, можливостей, виборів, горизонтів; спрямуванні до зростання якості життя у новому балансі.

1. Діденко В., Табачковський В. Світогляд. Філософський енциклопедичний словник / В. І. Шинкарук (голова редколегії) та ін. ; Л. В. Озадовська, Н. П. Поліщук (наукові редактори). Київ : Абрис, 2002. С. 569.

2. Дичковська Г. О. Аналіз політичних ідеологій крізь призму концепції позитивної психотерапії. Життя, конфлікти і любов у транскультурному світі : збірник матеріалів IX науково-практичної конференції 3 позитивної психотерапії Н. Пезешкіана (м. Одеса, 2-4 червня 2017 р.). Одеса. 2017. С. 13-20.

3. Донченко О., Романенко Ю. Архетипи соціального життя і політика (глибинні регулятиви психополітичного повсякдення): монографія. Київ : Либідь, 2001. 334 с.

4. Карпенко 3. С. Аксіологічна психологія особистості. Івано-Франківськ : Лілея-НВ, 2009. С. 326-375.

5. Пезешкиан Н. Психосоматика и позитивная психотерапия. Москва : Медицина, 1996. 463 с.

6. Пезешкиан Н. 33 и 1 способ партнерства. Москва, 2005. 288 с.

7. Пезешкиан Н. Психотерапия повседневной жизни. Тренинг воспитания партнерства и самопомощи. Москва : Медицина, 1995.

8. Носсрат Пезешкиан, Навид Пезешкиан. Как позитивно преодолевать усталость и перенапряжение. Черкасси : Брама-Украина. 2013. 192 с.

9. Радченко О. Зміна світоглядних настанов у методі позитивної психотерапії. Життя, конфлікти і любов у транскультурному світі : збірник матеріалів IX науково-практичної конференції 3 позитивної психотерапії Н. Пезешкіана (м. Одеса, 2-4 червня 2017 р.). Одеса, 2017. С. 173-176.

10. URL: http://www.positum.org. 